\title{
A PROPAGANDA TERMÉSZETE
}

\author{
Virán yi Péter \\ peterviranyi@t-online.hu
}

D O I : $10.20520 /$ J E L - K EP .2019.3.3

\begin{abstract}
Absztrakt
Tanulmányom a szakirodalom segítségével a propaganda történetén keresztül egyrészt kísérletet tesz a propaganda fogalmának tisztázására, másrészt a propaganda természetének bemutatásával egy szélesebb történelmi-társadalmi összefüggésre kíván rámutatni. Szembeállítottam a különböző definíciókat és kísérletet teszek egy saját értelmezés megfogalmazására. A propaganda a társadalmi kommunikáció egyik formája. Társadalmi termék, amelyet a társadalom tagjainak meggyőzésére állítanak elő. Az általam használt megfogalmazás főleg a propagandának a politikai marketinggel és reklámmal való kapcsolatára épül. Néhány sajátosságát a gyakorlat oldaláról is megvizsgáltam, többek között olyan témaköröket érintve mint a propaganda viszonyulása az információhoz és az igazsághoz, a propaganda intézményeinek egymáshoz való viszonya, a propaganda és a média kapcsolata, valamint a propaganda és a demokrácia összefüggései.
\end{abstract}

\section{Kulcsszavak}

marketing, reklám, politikai propaganda, média, indoktrináció, információ

\section{THE NATURE OF PROPA GANDA}

\section{Pét e r Virán yi}

\begin{abstract}
My paper focuses on two bundles of questions. On the one hand, by overviewing the literature and the history of propaganda, I try to clarify the concept of propaganda, and on the other hand, by analysing the nature of propaganda, I would like to point out a wider historical and social relationship. I contrast the different definitions of propaganda and formulate my own interpretation of it. Propaganda is a form of social communication. As a social product, it is developed for the persuasion of the members of society. The wording I use is mainly based on the relationship between propaganda and political marketing and advertising. Among other things, I try to throw light on the relation of propaganda to information and truth, the relationship between propaganda and its institutions, the relationship between propaganda and media, the relationship between propaganda and democracy.
\end{abstract}

\section{Keywords}

marketing, advertising, political propaganda, media, indoctrination, information 


\title{
A PROPAGANDA TERMÉSZETE
}

\author{
Virányi Péter
}

„A közvéleményt meg lehet mérgezni, de csak olyan méreggel, amelyik ízlik neki."

(Fjodor Mihajlovics Dosztojevszkij)

Tanulmányom két területre irányul. Egyrészt a szakirodalom segítségével kísérletet teszek a propaganda fogalmának tisztázására, másrészt a propaganda természetének bemutatásával egy szélesebb történelmi összefüggésre kívánok rámutatni. Ehhez felhasználom Jonathan Auerbach és Russ Castronovo amerikai professzorok 2014-ben megjelent, a propagandáról írott gondolatait.

\section{Az első propaganda}

Adam Clarke brit metodista teológus szerint a propaganda a Bibliáig vezethető vissza. Isten tiltó parancsa a hamis beszámolók terjesztésére vonatkozóan a későbbi kommentátorokat arra buzdította, hogy óvjanak a ,hazug hírek terjesztőitől”, akiknek az a bünük, hogy elhintik a széthúzás és a gyanakvás magvait, és megakadályozzák a béke megszilárdulását a földön. A tilalom a Tórából ered: „Ne terjessz rágalmakat néped között!” (Mózes 3. könyve, a Léviták szolgálatáról 19:16. Új fordítású Biblia) A Talmud-bölcsek még a Tóra intelmeit is tovább szigorították: a pletykát és a hamis híresztelést minden baj forrásának tartották olyannyira, hogy egyenértékünek tekintették az Istentagadással. Angliában 1275-ben már királyi rendelet tiltja a hamis hírek terjesztését. „John Wesley, anglikán lelkész 1739-ben írt széljegyzete sze-rint az isteni tiltás nem pusztán rémhírek terjesztésére, hanem azok befogadására is vonatkozik. Az üzenet igazsága vagy hamissága csak az egyik fele annak, aminek megítélésére a Biblia utasít. Legalább annyira jelentősek, ha nem még jelentősebbek azok a helyek, amelyek az ókori média-láncolatban összekapcsolták a közlőt a befogadóval." (Auerbach-Castronovo 2014) ${ }^{1}$.

A kommunikációs lánc e két végének összekapcsolásai olyan cselekvésformák, amelyek látszatra hétköznapi cselekvések, de a hatalmuk mérhetetlenül nagy: a terjesztés, a forgalmazás és természetesen a propagálás. „A meggyőzés használatairól és etikájáról folyó viták legalább Szókratész és a szofisták közötti klasszikus vitára vezethetők vissza. Noha Platón Gorgiásza kétségeket fogalmaz meg a meggyőzés erkölcsösségét illetően - vajon a meggyőzés nem pusztán fortély, amellyel az érzelemre hatunk, és megalapozatlan ítéleteket hozunk létre? -, mindenesetre a céljaink számára az mindenképpen jelentőséggel bír, hogy ez a dialógus nem mérlegeli az ilyen típusú meggyőzés léptékét, sem pedig azokat az anyagi esz-

${ }^{1}$ Itt és a továbbiakban néhány idézetnél nincsenek feltüntetve az oldalszámok. Ennek az az oka, hogy az interneten online elért szövegeknél gyakran nincsen oldalszámozás. 
közöket, amelyeket a retorika használ. Cicero tudományosabban fogalmazott, a meggyőzés három céljaként az elkápráztatás, a tanítás és a meghatás fogalmát adta meg." (AuerbachCastronovo 2014)

A propaganda kifejezés a latin propagare, 'terjeszteni' jelentésü igéböl ered, és annak a kongregációnak a feladataként vált hangsúlyossá, amelyet XV. Gergely pápa 1622. június 22én alapított a katolikus hit terjesztésére. „A Sacra Congregatio de Propaganda Fide létrehozását az kényszerítette ki, hogy Európa jelentős részén katonai eszközökkel nem lehetett megállítani a protestantizmus terjedését, ezért más eszköz után kellett nézni... [A propaganda] a hit vatikáni terjesztéséhez kapcsolódó jelenség, [...] a területnövelést konnotálja, amit gyakran a hódítással kapcsolnak össze. Ritkábban a kertészeti gyakorlatra utal, ahogy az ültetéssel [...] elősegítik a növények sokasodását. Kulturális gyakorlatként a propaganda nem kevesebbel foglalkozik, mint azokkal a módozatokkal, ahogy az emberi lények kommunikálnak, különös tekintettel a magatartásformák, a képek, a hitek elöállítására és széles körü terjesztésére." (Auerbach-Castronovo 2014)

A propaganda nem sokáig maradt meg vallási-egyházi kontextusban. Kezdetben a propagandát főleg az új müvészeti ágak, technológiai újdonságok népszerüsítésére használták. Például a reformáció idején a propaganda sokat segített a nyomtatás elterjedésében. A lutheri új egyházszervezeteknek őket szolgáló könyvekre volt szükségük. „Noha a fogalmat eredetileg a katolikus egyház hozta forgalomba, ezt követően az etimológiája egy döntő eltolódásra utal a francia forradalom idején, amikor a terminus jóval szekularizáltabb intézmények egész sorához kerül át. Ezt a fogalmat használták 1790-től kezdődően egész Európában mind a radikálisok, akik az Ész evangéliumát óhajtották terjeszteni, mind pedig az ellenforradalmárok, akik attól tartottak, hogy a 'propaganda', amelyet a 'gonosz újítók' által teremtett metaforikus szörnyként képzeltek el, viszályt fog szülni szerte a világon.” (Hunt 1984: 41) Ebben az újonnan előálló politikai kontextusban a propaganda vált a civil társadalom létrehozásának új bázisává azáltal, hogy széles körben hoztak olyan eszméket forgalomba, amelyeknek a középpontjában az általános szabadság és egyenlöség állt.

A politikai propaganda tulajdonképpen a politikai versengéssel és a politikai harccal egyidős. A modern politikai propaganda - az ideológia és a politika fúziójával, illetve a nyomdatechnika gyorsan terjedő eszközeinek felhasználásával - a francia forradalom idején jelent meg. Jean-Marie Domenach 1950-ben írt La propagande politique (Politikai propaganda) címü munkájában így fogalmaz: „Akkor folyt le az első propaganda-hadjárat, s az volt az első háborús propaganda. Akkor szabadult fel és szervezkedett első ízben egy nemzet olyan doktrína nevében, amely egy csapásra az egyetemest célozta. Első ízben társul egy világnézet expanziója a bel- és külpolitikához, s e tény már önmagában természetszerủen kitermeli a propagandát." (Domenach 1973: 48) A propaganda történetén végigtekintve folyvást ezt az öszszefüggést fedezzük fel, vagyis azt, hogy a propaganda tulajdonképpen nem más, mint a háború folytatása vagy helyettesítése egy másfajta technikával, netán hozzájárulás egy háború kirobbantásához. Elég csupán Joseph Pulitzer és William Randolph Hearst sajtóvezérek háborúval felérő vetélkedésére gondolni.

A propaganda a társadalmi kommunikáció egyik formája. Vagyis társadalmi termék, társadalom szülöttje, és csak ott müködik. De nem a társadalom egésze hozza létre, hanem mesterségesen állítják elő a társadalom tagjai számára hasonlóan az interperszonális vagy a csoport- vagy a szervezeti avagy a tömegkommunikációhoz. Ha tovább megyünk ezen a logikai síkon, akkor Umberto Eco gondolataival is találhatunk összecsengést. Ö ugyan a tömegkultúráról szólt, amikor azt írta, hogy a „kultúraipar mindig is hajlamos volt arra, hogy elöre csomagolt hatásokat adjon el, hogy a termékhez mellékelje a használati utasítást, az üzenethez a kiváltandó reakciót” (Eco 1976), mégis érdekesnek tünhet, hogy ha a kultúraipar szót 
behelyettesítjük a propagandával, minden megnyilvánulásában ott találjuk a jellemzőit: tipizálást, sztereotipizálást, konzervativizmust, mesterkéltséget, manipulálást.

Tanulmányozása rendkívül nagy jelentőségű a müvészettörténet, a történelem, a teológia, a kommunikáció, az oktatás, a médiatanulmányok, az irodalmi elemzés, a retorika, a kultúraelmélet, politikatudomány, a pszichológia és a szociológia területén. „Mivel a propaganda olyan sok vizsgálati mezőt fon át a társadalomtudományokban, megújult és kitartó figyelmet igényel, mivel azt ígéri, hogy felélénkíti az olyan, egymással átfedésben levő fogalmakat, és maga is megújul az olyan fogalmak által, mint amilyen az ideológia, a publicitás, vagy az indoktrináció. A propagandának messze mutató következményei vannak, és mint összefüggő gyakorlat vagy gyakorlatok kötege alkalmas a célzott vizsgálatra, mivel sajátos eredettel és gazdag történelemmel bír, ami segít fogalmat alkotni arról, hogy a jelenben miként kerülnek információk forgalomba." (Auerbach-Castronovo 2014).

\section{A propaganda sokféle meghatározása}

A propaganda fogalmának meghatározása meglehetősen nehéz, mert nem alakult ki egységes vélemény sem a tárgyát, sem a feladatait illetően. Ezért a propagandáról - vagy az egyes részletkérdéseiről - szóló feldolgozásokban a legkülönfélébb értelmezési lehetőségek fordulnak elő. Azért van ez így, mert ez a tevékenység annyira szerteágazó és összetett, hogy nem lehet pár mondattal ,jó” vagy „rossz” dologként beskatulyázni.

Karl Erik Rosengren, a svédországi Lund egyetem kommunikáció professzora szerint „propagandán nagyjából olyan, többé-kevésbé elfogult információt értünk, amit egy kormányzat vagy más hatalmi pozícióban levő szervezet saját érdekei szolgálatára terjeszt”. (Rosengren 2008: 201)

Anthony R. Pratkanis és Elliot Aronson amerikai pszichológusok a propagandán tömeges befolyásolást értenek, amely jelképekkel manipulál, és beveti a lélektan eszközeit. „A propaganda egy bizonyos nézet kifejtése azzal a végső céllal, hogy a befogadók tegyék magukévá a szóban forgó nézetet.” De tovább is mennek, amikor így folytatják: „A propaganda általában egy eszmerendszer, egy ideológia elfogadtatását szolgálja egy közönséggel, ha kell, hazugság és manipuláció útján.” (Pratkanis-Aronson 1992: 204)

Mielőtt még az első világháború tapasztalata mellékzöngékkel terhelte volna meg a propaganda megértését, a fogalomhoz kevésbé eldöntött jelentések társultak. Az atrocitásokról szóló hamis történeteknek és hazafias látványosságoknak az áradata 1914 és 1918 között nemzeteket és emberek tömegeit vezette egy elhúzódó háborúba. A propaganda első világháborús receptje így szólt: „Elfogult nézetek terjesztése, gyakran hazugság és csalás alkalmazása révén.” (Pratkanis-Aronson 1992: 204) „Németországban népszerü volt az a nézet - melyet Hitler is vallott -, hogy a szövetségesek remek propagandájuk miatt nyerték meg az első világháborút. Hitler képtelen volt elhinni, hogy az erös német hadsereget tiszta eszközökkel győzték le. Kellett lennie valami mágiának, amellyel a britek és az amerikaiak megverték ezt a legyőzhetetlen sereget - csak hadi eszközökkel ez nem történhetett volna meg. Ö egy ilyen varázsszert látott: a propagandát." (Múlt-Kor 2018)

Az 1920-as és 1930-as évek közgondolkodását és tudományos gondolkodását a társadalmi kommunikációval kapcsolatban a lövedékelmélet (bullet theory) avagy injekcióstü modell jellemezte. Eszerint a média nagy és közvetlen hatást gyakorol az emberekre: a nyomtatott sajtóból, filmekből és filmhíradókból, köztéri plakátokból és a rádióból érkező üzenetek mintegy lövedékként csapódnak a közönség elméjébe, maradandó elváltozást okozva benne. Az elméletet a legkoherensebb formában Harold Lasswell (1902-1978) kommunikációkutató fejtette ki az 1927-ben írt $A$ világháború propagandatechnikái címü munkájában (Lasswell 1927). Lasswell arra volt kíváncsi, hogy az első világháborúban alkalmazott pro- 
pagandatechnikák hogyan tudtak tömeges véleményváltozást kiváltani, és ezzel lángba borítani Európát. A közönséget olyan egynemü masszának tételezte, amelynek valamennyi tagja egyformán reagál a lövedékként rá záporozó üzenetekre. A korabeli társadalomelmélet ténynek tekintette a személyes kötelékek meglazulását, a hagyományos identitások felbomlását, a társadalom atomizálodását (később a Riesman-i „,magányos tömeg” megjelenését); a közönség kiszolgáltatottá válik a média manipulációs törekvéseinek, és a propaganda a néptömegek becsapásának, félrevezetésének hatékony eszközévé válik (Bajomi-Lázár 2006).

Lasswell részletesen leírta a sikeres propaganda eszközeit, köztük az ellenségkép megteremtését és a tudatos hazudozást. Ellenségnek jól azonosítható csoportokat vagy személy(eke)t kell megtenni, olyanokat, akik alkalmasak arra, hogy a befogadók rájuk vetíthessék kudarcaikat, elnyomottságukat, sikertelenségeiket, és őket okolhassák saját nyomorúságukért, és bünbakokat képezhessenek belőlük. A tényleges külső problémákat és válságokat fel kell nagyítani. Ez is segíti annak a nézetnek az elterjedését, hogy külső erők, az ország ellen támadók és összeesküvők a felelősek a nehézségekért. Lasswell kiemelte, hogy a háború megnyeréséhez egységes nemzeti támogatásra volt szükség, s ehhez az emberek tudatát kell ellenörzés alatt tartani. Az ellenséget ördögi természetünek kell ábrázolni, ugyanakkor rá kell mutatni, hogy nem legyőzhetetlen. Amennyiben hazudunk, akkor azt úgy tegyük, hogy csak azt követően leplezödjünk le, amikor a hazugság révén elindítani kívánt folyamatok már viszszafordíthatatlanokká váltak. Alig néhány évvel később ezek a képzettársítások visszaigazolódtak, amikor a náci birodalom a propagandát az invázió és a népirtás eszközévé változtatta. Joseph Goebbels propaganda-miniszter szerint a lényeg ,abban áll, hogy az embereket olyan öszintén, olyan mélyen nyerjük meg egy eszmének, hogy végül teljesen a magukévá tegyék." (Doob 1950)

A propaganda vizsgálatának Lasswellhez hasonlóan kiemelkedő személyisége volt az USA-ban Edward Bernays (1891-1995), aki „,nem csupán szakírója, hanem művelője is volt a propagandának: nagyvállalatoknak éppúgy adott tanácsokat, mint amerikai elnököknek.” (Kiss 2006) Mủvei, így a leggyakrabban említett Crystallizing Public Opinion (New York, Boni and Liveright, 1923) és a Propaganda (New York, Horace Liveright, 1928) hatást gyakoroltak a náci vezetőkre is, számos gondolata átkerült a Mein Kampfba, az általa írott könyvek ott sorakoztak Goebbels polcán. Bernays a propaganda és a public relations első komoly tudósa, aki párhuzamot vonva a két tevékenység között, a propaganda jelenségének megértéséhez egészen az antropológiai alapokig ásott le. Eszmerendszerében és módszertanában Gustave Le Bon tömeglélektani és Wilfred Trotter szociálpszichológiai tanait Sigmund Freud pszichoanalízisével ötvözte. Neki köszönhetjük az 'álesemény' ötletét és elterjedését. Ez olyan esemény, amelyik kifejezetten PR, illetve propaganda céllal jön létre azért, hogy egy személynek, csoportnak, szervezetnek, ügynek, eszmének kedvező tömegkommunikációs tálalást biztosítson. Ilyenek például a sajtótájékoztatók és az ünnepélyes koszorúzások. Ha a propagandista képes arra, hogy az eszméket eseményekké és hírekké változtassa, akkor azok nagyobb figyelmet vonzanak és könnyebben befogadhatóvá válnak. (Kiss 2006)

\section{Reklám és propaganda - propaganda és reklám}

Kassák Lajos a Nyugat folyóiratnak A reklám és a müvészet címü tanácskozásán 1929-ben így foglalt állást: „A reklám és a propaganda közti különbség szerintem az, hogy a reklám valami üzleti vállalkozás produktumát dicséri, a propaganda valami közhasznú dolgot akar belevinni a köztudatba. A reklám egy cikket a másik cikk fölé emel: a propaganda kulturális munkát fejt ki." (Virányi 2017: 62) Tény, hogy a propagandát leggyakrabban a politika használja, de a reklám nem szúkíthető le csupán a kereskedelmi hirdetésekre. Vajon mit kezdenénk a politikai vagy a társadalmi célú hirdetésekkel, azokkal a reklámokkal, amelyek nem egyértelmủen árut vagy szolgáltatást reklámoznak, hanem a helyes életmódra, életvitelre, 
helytelen szokások megváltoztatására, adományozásra, választásokra, egészségünk védelmére stb. hívják fel a figyelmünket? „Amíg teljesen érthetőnek tartjuk, hogy egy színes nyakkendő, egy doboz mogyorós tejcsokoládé, egy Ford kocsi vagy akár egy verseskötet megvásárlásához való kedvet ösztönünk, képzeletünk forrásaiból merítve, ezt az ösztönt és képzeletet igyekszik erősíteni bennünk a reklámművészet egész érzéki apparátusával az, aki el akarja adni nekünk; ugyanakkor riadtan és tétován tátjuk el szájunk, mikor ezekkel az eszközökkel a helyes politikai gondolkodás, az embertársainkkal való viselkedés, a jól felfogott közérdek elvont, csak értelmi képességekből, megismerésből, belátásból, okoskodásból táplálkozó eredményét igyekeznek elfogadtatni a tömeggel.” (Macskássy 1998: 52) Urbányi János 1930-ban kiadott $A$ reklám kézikönyvében úgy fogalmaz, hogy a „propagandát üző az ellentétes nézeten lévővel (nem ellenféllel) békés úton, tárgyilagos, komoly érvek hangoztatásával kívánja véleményét elfogadtatni. Tárgy pedig a közügyekre vonatkozik.” Majd gondolatát így folytatja: „,propaganda és a reklám valamilyen pozitívummal kívánja a közvéleményt megtelíteni, az agitáció megelégszik azzal, hogy egy negatívumot tud a közvéleménybe beoltani”. (Urbányi 1930: 5-6)

Ha a marketing oldaláról nézzük a propagandát, nem találhatunk kivetnivalót abban, hogy a reklámmal szoros kapcsolatban áll. „A marketing értelmezése szerint minden a 'termék' kategóriába tartozik, ami eladható, legyen az jószág, szolgáltatás, ötlet stb. Ez teljesen megfelel a propaganda termékszerü megközelítésének. Egyfajta szolgáltatásról van szó. Ahogyan a politikai erők is egyre inkább önmagukat, illetve (szak)politikai ígéretüket akarják megismertetni, így válik egyre hasonlóbbá a marketing és ezen belül a politikai marketing a propagandához.” (Kiss 2006) A politikai propaganda és a politikai marketing, annak ellenére, hogy több publikáció egymás szinonimáinak tartja e fogalmakat, nem tekinthetök azonosak. A mindennapi szóhasználatban a politikai propaganda föleg a diktatórikus társadalmakkal asszociálódik úgy, mint az éppen hatalmon lévő pártok, illetőleg a kormány kommunikációja. A politikai marketing fogalomköre viszont jobban kötődik a demokráciához: pártok, politikusok kontextusában, civil mozgalmak körében használják. A propagandista államosítja a médiát vagy nyomást gyakorol rá, míg a politikai marketinges megvásárolja azt.

Bernard Brochand és Jacqes Lendrevie $A$ reklám alapkönyve címü munkájukban úgy fogalmaznak, hogy „a reklám elkötelezett tömegkommunikáció”, majd úgy folytatják, hogy „tiszta lapokkal játszik, nem titkolja természetét és szándékait. A hirdető kézjegyével hitelesíti állításait és vállalja értük a felelősséget. A reklám kényszer nélkül cselekszik..." (Brochand-Lendrevie 2004: 12) A politikai nézetek ugyanolyan árucikkek, mint az ipari és a szolgáltatási termékek, s ezért ugyanolyan reklámkampányokban népszerüsíthetők. „Régi igazság, amit a gyakorlat bizonyít, miszerint: ha minden egyéb feltétel azonos, vagy azonosnak látszik, a vevők az ismerősebb márkát választják." (Aronson 1987: 7) Nincs ez másképpen a politikai propagandánál sem, amely arra épít, hogy az emberek többsége általában nem, vagy csak korlátozottan érti, fogja fel, hogy mi játszódik le a gazdaságban vagy a politika színterén, és bizonyos társadalmi folyamatoknak milyen hatásaik vannak. A politikai propaganda a modern kereskedelmi reklámhoz hasonló elven alapul: az áruként eladandó politikai irányzatról vagy politikusról azt sugallja, hogy megoldást kínál a problémákra. A politikai propaganda azt akarja elérni, hogy a befogadó úgy vélje, az általa közvetített valóságmodell a helyes, vagy legalábbis az elfogadható valóságképek egyike (Aronson 1987: 73). A politikai propaganda azonban, eltéröen a kereskedelmi reklámoktól, többnyire nem hív fel közvetlen cselekvésre, és a hatékonysága nem mérhető az eladott áru vagy szolgáltatás menynyiségével, mint a reklámé. Ettől eltér a választási hirdetés vagy a háborús propaganda, amely a választáson való részvételre, illetve a háború tevőleges támogatására vagy a hadseregbe való belépésre szólít fel.

Jakusné Harmos Éva A kereskedelmi és a politikai propaganda nyelvi eszközei címü tanulmányában arra hívja fel a figyelmet, hogy ,a hírszövegek írói is azt a látszatot keltik, hogy tényszerüen információkat közölnek a világról. A témák kiválasztását és a hírek 
szerkesztését azonban egyaránt befolyásolja a közlő valóságmodellje. A befogadóra való hatás szándéka itt másként jelentkezik, mint például a kereskedelmi propaganda (reklám) esetében. A kereskedelmi reklám arról akarja meggyőzni a fogyasztót, hogy szüksége van a kínált termékre vagy szolgáltatásra; hogy az megoldást jelent valamilyen problémájára, ezért meg kell vásárolnia" (Jakusné 2005: 426). Egy eszmét, nézetet, ideológiát éppen úgy kell reklámozni, mint egy mosóport; eszközökben, módszerekben nincs különbség.

$\mathrm{Az}$ 1929. évi müncheni Nemzetközi Reklám kiállításon, a legelső kiállító-teremben feltünő plakát fogadta a látogatót. „A plakát egy emberi fejet ábrázolt, abban a pillanatban, amikor egy hatalmas kalapács sújt rá. A plakát alatt ez a szó állt: A reklám) Azóta sem határozta meg száz és száz tanulmány ilyen pontosan a reklám természetét, mint ez a maró gúnnyal és józan logikával felrajzolt morbid plakát. Mert mi más a reklám, mint a csendes türéssel és beletörődéssel odatartott före hulló kalapács-ütés? A kalapács a reklám. A kalapács-ütés fogalmában benne van a reklám mindhárom alkotó eleme: a külső, szándékos erő, mely sújtani (hatni) akar, az eszköz, mely elvégzi ezt az ütést (hat), és végül az egyén legértékesebbnek mondott, valójában azonban legkönnyebben befolyásolható szellemi tulajdonsága: az ítélőképessége.” (Fekete 1940: 111) Ha e szövegben a „reklám” szót a „propaganda"szóra cseréljük, akkor az utóbbinak is megragadtuk a lényegét.

Összegezve a fentieket, ,a propaganda [...] a marketingkommunikáció elemeként egy olyan technika, amely elősegíti bizonyos nézetek, eszmék, ideológiák megismerését, terjesztését, bevésését, elsajátítását. Célja: hogy az emberek attitüdjét, érzelmeit, gondolkodását, magatartását, viselkedését egy adott nézettel kapcsolatosan az elfogadás irányába befolyásolja, megerősítse. Vagyis informál, befolyásol és tudatot formál. A propaganda által bevetett eszközök, elvek, eljárások, technikák, a médiumok, szervezetek a szüken értelmezett reklámozással azonosak. Mint technika, a reklámot utánozza. A propaganda a reklámozás eszközeit, módszereit felhasználva, nem csak értéket közvetít, hanem értéket is teremt." (Virányi 2017: 34)

\section{A propaganda néhány sajátosságáról Jonathan Auerbach és Russ Castro- novo Tizenhárom tézis a propagandáról címú írása alapján}

\section{A közbeszédben a fogalom igencsak negativ kicsengésü}

Ma a „propaganda” szó meglehetősen negatív konnotációval rendelkezik, említésekor Hitler, Göbbels, Sztálin, a vörös csillag és választási kortes beszédek ugranak be, és nem például társadalmi célú, pozitív tartalmú hirdetések. Azonban a tekintélyelvü rendszerek - például a hitleri Németország, a sztálini Szovjetunió, a Mao vezetése alatti időszakban Kína, vagy Fidel Castro idejében Kuba - pozitív értelemben használták. Ennek is tudható be, hogy a propaganda említése rossz érzést vált ki az emberekben, pedig a tartalma nem csak a manipulációról, a hazugságról szól. "A propaganda önmagában nem gonosz vagy immorális. George Orwell, amikor a II. világháború alatt a $\mathrm{BBC}$ Tengerentúli Hivatalában dolgozott rádiós előadóként, azt a látszólagos paradoxont fogalmazta meg, hogy 'minden propaganda hazudik, még akkor is, ha némelyik az igazat mondja.' (Naplóbejegyzés, 1942. március 14.) Orwell arra tapintott rá, hogy nem egy bizonyos állítás igaz mivolta a központi kérdés, ami alapján megítélhetjük a propagandát. Ehelyett a problémát sokkal súlyosabbként fogalmazza újra azáltal, hogy a terjesztés minden aktusát lényegileg tisztességtelenként ítéli el. De mint ahogy azt már korábban említettük, ez a szinte önkéntelen közhely, amely szerint a propaganda természetétől fogva tisztességtelen és megtévesztő, egyenesen következett a propaganda gyakorlatából, különösen az első világháború alatti és az azt követő kölcsönös vádaskodásból Németország és az ellenségei között. Ezzel szemben a propagandának az első világháborút megelőző majdnem háromszáz éves gyakorlata és fogalma egy sokkal jóindulatúbb történetet 
sejtet, mivel a fogalom az olyan mozgalmakhoz kapcsolódik, mint a szüfrazsett mozgalom, a rabszolgaság eltörlése és a környezetvédelem.” (Auerbach-Castronovo 2014)

Jacques Ellul (1973) szerint sokakban az a téves meggyőződés él, hogy a propaganda csupán hazugságokból áll, vagyis ami igaz, az nem is propaganda. Aki azonban úgy véli, hogy immunis a propagandára, mert meg tudja ítélni, mi igaz és mi nem, az csapdába esik. Ugyanis, amikor a propaganda tényszerü dolgokat állít, azt fogja hinni, hogy az nem propaganda. Egy szónak, fogalomnak önmagában nincs elöjele. Használatakor derül ki, hogy pozitív vagy negatív, jó vagy rossz tulajdonságokkal rendelkezik. De ez még mindig nem elég a megítéléshez, hiszen akár a metakommunikáció, akár a mögöttes tartalom, akár a konkrét szituáció (ahol és amikor a fogalmat használjuk) megváltoztathatja a szó, a fogalom értelmét. Például a „pozitív” szó önmagában véve a köznyelvben jót jelent, valamilyen jó dologra asszociálunk hallatán. De vajon ezt gondoljuk akkor is, amikor valakinek a tüdöröntgen lelete mutat ilyen eredményt?

\section{Propaganda és információ}

„A propaganda és az információ közötti viszony cseppfolyós, kontextustól és funkciótól függően változik. [...] Az időjárásról szóló információt is felhasználhatja az éghajlatváltozásról, a globális felmelegedésről, az üvegházhatásról szóló elkötelezett érvelés és az áltudomány: ez a változó nomenklatúra egyszerüen rámutathat arra, hogy az információ és a propaganda közötti határ változékony és labilis." (Auerbach-Castronovo 2014)

Vajon van-e különbség információ, igazság és propaganda között - teszi fel a kérdést Stanley B. Cunningham (1989). „Az információ és értelmezése természeténél fogva sokféle. A propaganda nem ott kezdődik, ahol a tényeket a hamisított adatok váltják fel, hanem ahol a propagandista elkezdi őket szelektálni, majd pedig interpretálni.” (Kiss 2006) Tanulságos, ahogy Hitler a Mein Kampfban vélekedett a propaganda feladatáról: „A propaganda funkciója nem az, hogy mérlegelje az emberek igazságát, hanem, hogy kizárólagosan hangsúlyozza a mi igazságunkat, amelyért müködésbe hoztuk. Dolga nem az, hogy az igazság tárgyilagos lenyomata legyen." (Rudas 2012)

Edward Herman közgazdász és Noam Chomsky nyelvész Az egyetértés-gépezet: A tömegmédia politikai gazdaságtana címü könyvükben leírt propagandamodell szerint a média és a hatalom viszonyát öt tényező határozza meg (Herman-Chomsky 2016). Öt olyan „szürő” létezik, amelyeken az információnak át kell jutnia, hogy a média terjeszteni kezdje. Ezeken a szürökön pedig szinte csak olyan hírek és vélemények juthatnak át, amelyek megfelelnek a mindenkori hatalom érdekeinek. Ez nem tudatos tervezés eredménye, e szürök mind elkülönült gazdasági folyamatok termékei, együttmüködve mégis propagandagépezetté alakítják a médiát.

1. A média tulajdonosi szerkezete és profitorientáltsága. A médiavállalkozások többnyire profitorientált üzleti vállalkozások: céljuk a piaci siker, nem pedig a nyilvánosság tájékoztatása.

2. Hirdetési bevételekböl nagyobb profitra tehet szert egy médiavállalkozás, mint pusztán a médiatermékek eladásából. Ez azt jelenti, hogy a hirdetők számára vonzó médiafelületek piaci előnyre tesznek szert és kiszorítják a többit, ám egyúttal kiszolgáltatottá is válnak a hirdetőknek.

3. A hírforrások szükössége, vagyis a média jórészt csak olyan forrásokból szerezheti be információit, amelyek a politikai és pénzügyi elit közvetlen befolyása alatt állnak.

4. A negyedik szürő az úgynevezett ,,flak”, azaz ,,lejáratás”, egy médiaállásponttal vagy müsorral kapcsolatos negatív visszhang. Ez érkezhet felháborodott nézőktől, megsértett közszereplőktől, de akár állami vagy kormányzati szervektől is. A kor- 
mányzat egy-egy nemkívánatos hírre reagálva olyan jogszabályokat is hozhat, melyek jócskán megnehezítik a média életét.

5. Végül a már igazi szitokszavakká vált neokommunizmus és neoliberalizmus fogalmak használata. Elegendő csupán az úgynevezett Finkelstein-formulára gondolni, miszerint: „címkézz valakit liberálisnak, építsd hozzá a nevéhez valahogy a jelzőt, és ismételd a végtelenségig." Ezt Finkelsteinről a kilencvenes évek végén Mark Mellman, egy washingtoni demokrata elemző cég, a Mellman Group vezetője nyilatkozta. „Sajátíts ki egy szót az emberek fejében” - ahogy Al Ries és Jack Trout fogalmazták meg Marketingháború címü könyvükben (Ries-Trout 1996).

A társadalom uralkodó osztályai, csoportjai - legyen szó akár diktatórikus, akár demokratikus társadalomról - mindig igyekeztek ellenőrzésük alá vonni a médiumokat. A CBS hírek egykori elnöke Richard Sabant így fogalmazott: „A mi feladatunk nem az, hogy azt adjuk az embereknek, amit akarnak, hanem hogy azt adjuk nekik, amit mi fontosnak tartunk." Azt pedig, hogy a média mit tart fontosnak, a tulajdonosok, a pénzhatalom háttér-emberei diktálják, a manipulációs szakértők csak végrehajtók.

Több teória született azzal kapcsolatosan, hogy az emberek miként válogatják ki a számukra fontos vagy az érdektelen információkat. Erre a kérdésre keresi a választ Joseph Klapper A tömegkommunikáció hatásai címü munkájában (Klapper 1969). Szerinte az emberek szelektíven érzékelik a feléjük záporozó információkat. A szelekciónak három szintjét különböztette meg:

1. Szelektív válogatás: az emberek nem követik figyelemmel azokat a médiumokat, melyek az ö véleményükkel ellentétes információkat közölnek

2. Szelektiv észlelés: ha mégis meghallanak olyan információt, ami az ő véleményükkel ellentétes, akkor azt egyszerüen semmibe veszik.

3. Szelektív emlékezés: ha (véletlenül) meghallgatják a véleményükkel nem egyező információkat, akkor azokat hamar el is felejtik.

Ez az információszelekció azért jöhet létre, mert az emberek lehetőség szerint kerülik a diszszonáns helyzeteket, próbálják nem meghallani azokat az információkat, amelyek felépült világképük újragondolására késztetnék őket. A média hatása nem a véleményváltozás kiváltásában, hanem a már meglévő vélemények megerösítésében mutatkozik meg (BajomiLázár 2006). A választási kampányok nem a biztos pártválasztókat célozzák meg, hiszen ők elkötelezettek egy párt mellett, hanem az ingadozókat, hogy érveket adjanak számukra a pártválasztáshoz.

A propaganda minden gyakorlatát intézmények viszonyában kell értelmezni. Így megkülönböztethetünk vallási propagandát, kultúra propagandát, politikai propagandát, kereskedelmi propagandát, állami propagandát, háborús propagandát és még hosszan lehet sorolni a fajtáit. „Míg a vallási intézmények hajlottak arra, hogy nyilvánossá tegyék propagandisztikus tevékenységüket, a nevelési intézmények gyakran szégyenlősek, amikor a propagandához való közelségükről van szó. A gazdasági, politikai és vallási ügyeket érintő, közvetett és kevésbé erőszakos jellegü propagandát indoktrinációnak hívjuk.” (Rosengren 2008: 203) „Nincs olyan ország, ahol a tömegkommunikációban megjelenő tartalmak egy része ne lenne indoktrinatív jellegü, és nemcsak a gazdasági és politikai kontextusokban, hanem a szórakoztatásban, a fikcióban és oktatás minden területén is. Általánosan fogalmazva a propaganda és az indoktrináció egyaránt a szocializáció és reszocializáció sajátos esetének tekinthető." (Auerbach-Castronovo 2014) Karinthy Frigyes a töle megszokott humorral és iróniával így érzékeltette a helyzetet: „,...] Egy új pedagógus a fizika és matematika törvényeit egyszerre csak úgy kezdi népszerüsíteni, hogy bevezetés és magyarázás helyett plakátokat és lelkesítő füzeteket olvastat tanítványaival. 'Éljen az egyedül érvényes binomiális tétel!', 'Püthagorasz 
hívei, egyesüljetek!', 'Csak az egyszeregy és az önbizalom vezethet ki a káoszból!', 'Harcoljunk a hármasszabályért és mienk a jövő!', 'Einstein ennek a nemzedéknek Megváltója!' feliratokkal, s kísérletek bemutatása helyett kokárdás, lampionos, sisakos felvonulást rendez tanítványaiból, tüntetni Newton igazsága mellett, mielőtt Newton igazságát kipróbálta és bebizonyította volna előttünk. [...]” (Pesti Napló 1935. május 7.)

\section{A propaganda minden médiumban szerepet kap}

Annak, hogy a propaganda csak korlátozott mértékben és áttételesen képes befolyásolni a közönséget, az az oka, hogy a különböző médiumok, amelyek a csatorna szerepét töltik be a propaganda vonatkozásában (is), csak egy az embereket befolyásoló számos tényező között, így nem lehetséges teljesen egy adott médium tulajdonságai alapján definiálni. A befolyásoló tényezők sorában ott van a család, az iskola, az egyház, a munkahely, a barátok, a kortárscsoportok stb. A különböző szocializációs ágensek különböző nézeteket, értékeket, mintákat közvetítenek, és együtt hatnak az emberekre. Ezen hatások között pedig a propaganda hatását nem lehet elkülöníteni a többitől - már csak azért sem, mert a különböző társadalmi hatások a médiát, rajtuk keresztül a propagandát is folyamatosan alakítják.

A történelem során kialakult sokcsatornás és sokszínű médiapiacon nem beszélhetünk egységes propagandaképröl. Az azonos propagandisztikus célok gyakorta ellentétes üzeneteket fogalmaznak meg. Gondoljunk csak a pártok választási üzeneteire: a cél azonos, az adott párt győzelme, az üzenetek azonban igencsak eltérőek. „A média hatásának kérdései különösen a politikai propaganda és kampány, a médiaerőszak és a gyülöletbeszéd kontextusában merülnek fel. És miután ezek a napi politizálás részei - és legyen ez formális, vagy informális fórumokon - az információ forrás a média. De nem a hírvivő tehet a hírről. Amiről viszont tehet, hogy hogyan, miképpen tálalja, csomagolja." (Bajomi-Lázár Péter 2006)

\section{A propaganda akkor hatásos, ha totális}

A totalitárius rezsimek úgy maximalizálják a hatalmukat, hogy kiterjesztik a felügyeletüket a szigorú értelemben vett politikán túl a kultúrára, a nevelésre, oktatásra és nem ritkán az egyházra. Nem egyszer előfordul, hogy a törvényhozás házában imádkoznak, a templomban meg politizálnak. Jacques Ellul, francia szociológus Propaganda: The Formation of Men's Attitudes címü könyve fordulópont, sőt inkább töréspont a propagandakutatások történetében (Ellul 1973). A propagandakutatás sokáig föleg a háborús és a totalitárius propagandával foglalkozott. Ellul azonban olyan felfogást dolgozott ki, amelynek alapján a propaganda feltalálási helye sokkal szélesebb, mint korábban gondolták. A propaganda nemcsak a diktatúrák kelléke, de a demokratikus elveket hirdető technológiai társadalomnak, a szakértők irányította világnak is szükségszerü, kiküszöbölhetetlen eleme. Ellul a modern társadalom és ezen belül a propaganda alapvető logikáját keresi a müveiben. Ezt a technikában találja meg. Nem a gépek uralmáról van szó, hanem egy gondolkodásmódról, amely mindent technikai problémaként fog fel. A propaganda a mindenütt problémákat látó és megoldásokat kereső modern gondolkodás terméke, a technikai univerzum része, azaz: eszköz. Az eszköznek pedig egyedül a hatékonysága számít. Íme a propaganda technikájának néhány jellemzője:

- Egyszerre fordul az egyénhez és a tömeghez.

- Totális: ,az összes rendelkezésére álló eszközt alkalmaznia kell, nem csupán egyegy eszközt, mintegy véletlenszerúen. Mindegyik eszköz másképpen hat, más oldalról dolgozza meg a közönséget. Az egyes eszközöket egymással kölcsönhatásban kell alkalmazni." (Kiss 2006) Tömegkommunikációs szempontból a totális propaganda lényegéhez tartozik, hogy a tömegkommunikációs csatornákhoz kapcsolódó technikai eszközöket egyetlen hatalmi központból irányított intéz- 
ményrendszer müködtesse. A sajtón, rádión, televízión és tömegrendezvényeken közvetített politikai gondolatok összekapcsolódnak a szórakoztatással. A néptömegek szórakozása-szórakoztatása közben újra és újra felbukkannak politikai üzenetek, jelszavak. A kanadai kommunikáció-teoretikus McLuhant idézve: "Bármely médium vagy technológia 'üzenete' az a lépték-, ritmus- vagy mintaváltozás, amit az adott médium vagy technológia létrehoz az emberi tevékenységekben, kapcsolatokban." (McLuhan 2001: 7) A média és az általa közvetített propaganda nemcsak az emberek eszéhez és ítélöképességéhez szól, hanem az emberi személyiség érzelmi tényezőihez is: az ideológiai racionális összetevő egyben emotív tartalom hordozója is.

- A hatékony propagandának „folyamatosnak és tartósnak kell lennie. A propagandának sajátos zárt világban kell tartania az egyént, nem szabad olyan szüneteket hagynia, amelyek elgondolkodtathatják, és esetleg képessé tehetik arra, hogy mintegy kívülröl reflektáljon a propagandára. Ez a folytonosság azért is fontos, mert az ismétlés lényegi hatáseleme a propagandának. Az üzenet úgy ivódik be, ha állandóan ismételgetjük. Teljesen mindegy, hogy egy adott mondatnak van-e igazságtartalma vagy nincs, ha sokat ismételgetik, igazzá válik. Következésképpen a propaganda nem egyszeri lökésekkel dolgozik, hanem impulzusokkal, sorozatos ütésekkel, nehogy a hatás elhaljon." (Kiss 2006)

\section{Minél egyszerübben}

A propagandáról készült 20. századi tanulmányok a lakosságra úgy tekintettek, mint amelyet a manipuláció mesterei általában meggyőzhetnek, könnyen alakíthatnak és formálhatnak. Még mielőtt a nácizmus támogatta volna ezt a szemléletmódot, Friedrich Schillernek az 1795-ben az esztétikai nevelésről írott müvében megjelent az állampolgárokról, mint ,alaktalan tömegröl" alkotott kép, amely az állam gyakorlott szobrászkezére vár, hogy habozás nélkül erőszakot kövessen el rajta (Schiller 1960). Majd a tömegpszichológiai kutatások, köztük nem utolsó sorban Gustave Le Bon francia szociálpszichológus munkái erősítették meg azt a nézetet, hogy az emberek csoportként olyan tetteket is végrehajthatnak, amelyeket egyénenként soha nem tennének. A tömeg más, mint az alkotó individuumok összessége. A tömegben az egyén elveszti kritikai érzékét, és a tömeg esetleg pusztítóvá válik. Le Bon világosan fogalmaz: „Aki vezetni akarja a tömegeket, annak az érzelmeire, és sohasem az értelmére kell hatnia" - írta 1895-ben A tömegek lélektana címü könyvében. Ezt a véleményt a 20. század első feléig nagyon sokan osztották, később azonban a szociálpszichológia fejlődésével egyén és tömeg viszonyának kérdésében ellentétes nézetek is napvilágot láttak, melyek szerint a tömeg igenis visszavezethető az individuumokra. A tömeg belülröl differenciálható, el lehet különíteni olyan típusokat, amelyekre azonos magatartási minták, vágyak, attitüdök jellemzőek.

A propaganda nem intellektuális müfaj. Ez a megállapítás Hitlernél is nagy hangsúlyt kapott: „Nem szükséges, hogy a nép tudatosan gondolkodjék, hiszen az emberek felfogóképessége amúgy is meglehetősen korlátozott, intelligenciájuk csekély, viszont igen gyorsan felejtenek." (Rudas 2012) Ezért azon is könnyen túlteszik magukat, amikor a vezetők meglehetősen nagy, néha 180 fokos fordulatokat tesznek.

És hogy a náci propaganda működésénél maradjunk, Goebbels szerint a propaganda hatékonyságának egyik fő eleme az egyszerüsítés, és ennek meg is adta a receptjét (Doob 1950, Bacsárszki 2015):

1. Kerüld az elvont gondolatokat, és az érzelmeket vedd célba!

2. Kevés üzenetet küldj, de azokat folyamatosan sulykold!

3. Használj felszínes, általánosító véleményeket, sztereotípiákat! 
4. Az érvelés legyen egyoldalú - soha ne árnyalj!

5. Folyamatosan kritizáld az ellenfeledet!

6. Keress egy ellenségképet és folyamatosan rágalmazd! Ezek az elemek a történelem során univerzálisnak mutatkoztak - bármit és bárkit be lehet helyettesíteni, logikája a mai napig jól működik.

\section{A propagandának az érzelmek széles skáláját kell hasznosítania}

[A propagandának] „túl a negatív érzelmeken, mint amilyen a gyülölet, a félelem, az irigység, olyan pozitív érzéseket is magába kell foglalnia, mint az öröm, az élvezet, a biztonság, az odatartozás, a büszkeség, hazaszeretet, stb." (Auerbach-Castronovo 2014) Hitler is azt hangsúlyozta a Mein Kampfban, hogy ,a propagandának mindig a tömegek felé kell irányulnia. Feladata nem a tudományos igényü ismeretátadás, hanem a tömeg figyelmének felhívása bizonyos tényekre, eseményekre. Minden propagandának népszerünek kell lennie, és szellemi színvonalát a felvilágosítandók legkevésbé képzett rétegének befogadóképességéhez kell szabni." (Rubicon 2018: 69-75) Köztudott, hogy ha az érzelmeket célzó információ a befogadó olyan attitüdjeit célozza meg, mint például a harmonikusabb élet utáni vágy vagy a családi biztonság, akkor a reklámozott termék (politikai felhívás) is szimpatikusabbá válik számára.

Az amerikaiak az első világháború során létrehozták a Tájékoztatási Bizottságot (United States Committee on Public Information), aminek két fó célja volt. Egyik az ,atrocitás sztorik" vizsgálata: annak kiderítése, hogy hogyan lehet félelmet és gyülöletet kelteni, illetve olyan történetet konstruálni, amiből az derül ki, hogy az ellenség kegyetlen (megerőszakolja asszonyainkat, szétveri templomainkat, stb.). Hatékony módszer a félelemkeltés: aki fél, az nem száll szembe a propaganda által hirdetett „abszolút igazsággal”, sőt ő maga lesz elkötelezett, lelkes közvetítője. Másik taktika az ellenség vezetőinek módszeres karaktergyilkossága és lejáratása.

\section{A propaganda a demokratikus társadalmak hozadéka}

Találd fel a nyomtatott sajtót, és a demokrácia elkerülhetetlenné válik, jegyzi meg 1837-ben a skót történetíró, Thomas Carlyle, rámutatva, hogy a könyvnyomtatás feltalálása miként növeli meg oly módon az információ hatókörét és sebességét, hogy az egész lakosság a meggyőzés tárgyává válhat. (Carlyle 1837). Az amerikai filozófus, John Dewey 1927-ben így kontrázik: "Találd fel a vasutat, a telegráfot, a tömeggyártást, az emberek koncentrálódását a városokba, és a demokratikus kormányzás bizonyos formái, emberi számítás szerint elkerülhetetlenek." (Dewey 1927: 110) A szofisztikált elosztási technikák és a kiterjedt kommunikációs hálózatok valóban galvanizálták az Egyesült Államok lakosságát, de nem kizárólag az önkormányzatiság növelése, hanem az európai háborúba való beleegyezés érdekében. Míg a háborúba való belépést azzal a szlogennel igazolták, hogy „,biztosabbá teszik a világot a demokrácia számára", a háború alatt a propaganda gondoskodott arról, hogy a lakosság egyet is értsen az események ilyen értelmezésével. Ugyanígy napjainkban is leírhatnánk, hogy: találd fel a tévét, a mobiltelefont, az internetet, és szeretnénk azzal folytatni, hogy ebből (több, jobb) demokrácia következik. Úgy tünik azonban, hogy biztosabb tipp, ha pusztán annyit mondunk, hogy ezek az új kommunikációs eszközök a közösségi vélemények egyre erőteljesebb formálására tett kísérletek. „Megváltozott az egész információgazdálkodás, ami azt jelenti, hogy manapság szeretik elárasztani információval, adatokkal az embereket. Mi ennek a következménye? Nem az, amit a közkeletủ felfogás tart, hogy az állampolgár tájékozottabb lesz, ezért nem ül föl mindenféle propagandának, álhírnek. Ellenkezőleg: ha valakinek csak egy információt mondunk, azt esetleg képes ellenőrizni, de ha százat mondunk, akkor inkább csak összbenyomása alakul ki a dolgokról. De éppen ez a cél, az, hogy az emberek - miután nem 
képesek a rengeteg információ feldolgozására - a propagandista számára kedvező összbenyomásra tegyenek szert a hallottak, látottak alapján. A lényeg: értelmetlen cikkekkel elárasztani a médiát, hogy a valódi hírek ki se látsszanak alóluk. És ha ez kevés, akkor mesterségesen állítanak elő olyan konfliktusokat, melyek célja kizárólag az, hogy a lényegi problémákról eltereljék a figyelmet.” (Kiss 2006)

\section{Lezárás helyett}

„Az emberek propagandát fogyasztanak, de létre is hozzák és csomagolják a saját információikat, ugyanúgy, ahogy létrehozzák és megszövik saját igazságaikat." Érdemes végiggondolni: „,...] Azáltal, hogy eldöntheti, hogy eltávolítson-e egy bujtogató Youtube videót egy olyan társaság, mint a Google, amely saját felülettel rendelkezik, nagyobb hatalommal bír a szabad véleménynyilvánítás és a szellemi köztulajdon fölött, mint maguk az egyes kormányok. Azt is érdemes megjegyezni, hogy az egyház, az állam és a vállalati érdekek gyakran versenyeznek egymással, nem pedig kölcsönösen támogatják egymást, és mindezt együttvéve nem tudják totálisan blokkolni a terjesztés eszközeit. A 18. századi Franciaországban, hónapokkal Bastille bevétele elött nem pusztán egyetlen nyomda nyomtatott olyan pamfleteteket, amelyek Marie Antoinette szexuális kicsapongásairól elmélkedtek, és amelyek táplálták az Ancien Régime-el szembeni felháborodást. Ehhez hasonlóan nem pusztán egyetlen Twitter beszámoló volt, amely üzeneteket közvetített a Tahrir térről a 2011-es egyiptomi rezsimváltást célzó tömegtüntetések során. Mivel a nép sosem egyetlen entitás, a figyelem a terjesztés többszörös csomópontjaira kell, hogy irányuljon, amennyiben a propagandát a kommunikáció inkább horizontális formájaként fogjuk fel.” (Auerbach-Castronovo 2014)

A propaganda változékonysága és meghatározásának nehézségei meglehetősen bonyolulttá teszik ennek a tevékenységnek a teljes feltérképezését. A tanulmány kísérletet tett arra, hogy hozzájáruljon, hátteret, segédletet nyújtson a propaganda természetének tanulmányozásához. A propagandát olyan technikaként járta körül, amely a reklámmal azonos eszközöket és módszereket használ, sőt egy tágabb értelemben véve céljaik is azonosak: informálás, befolyásolás, tudatformálás. Ígéretet ad el, és befogadót vásárol. 


\section{IRODALOM}

Auerbach, Jonathan - Castronovo, Russ (2014) Tizenhárom tézis a propagandáról. Apertúra, 2014, tavasz. A szöveg eredeti megjelenési helye: Jonathan Auerbach - Russ Castronovo (2013) Thirteen Propositions about Propaganda. In: Jonathan Auerbach - Russ Castronovo (2013eds.) The Oxford Handbook of Propaganda Studies. Oxford University Press, UK. 1-12.

http://uj.apertura.hu/2014/tavasz/auerbach-castronovo-tizenharom-tezis-a-propagandarol/

Aronson, Elliot (1987) A társas lény. Budapest, Közgazdasági és Jogi Könyvkiadó.

Bacsárszki Ágnes (2015) Minden, amit tudni akartál a propagandáról. Media 2.0 http://media20.blog.hu/2015/09/20/a_propaganda_anatomiaja_368

Bajomi-Lázár Péter (2006) Manipulál-e a média? Médiakutató, 2006/nyár. https://mediakutato.hu/cikk/2006_02_nyar/04_manipulal-e_a_media/

Brochand, Bernard - Lendrevie, Jacques (2004) A reklám alapkönyve. Budapest, KJK - KERSZÖV Jogi és Üzleti Kiadó.

Carlyle, Thomas (1837) The French Revolution: A History. London, Chapman \& Hall. Project Gutenberg EBook 1301, 2006.

Cunningham, Stanley B. (1989) Smoke and Mirrors: A Confirmation of Jacques Ellul's Theory of Information Use in Propaganda. In: Smith III, Ted J. (1989ed.) Propaganda. A Pluralistic Perspective. New York, Praeger.

Dewey, John (1927) The Public and Its Problems. New York, Henry Holt.

Domenach, Jean-Marie (1973) La propagande Politique. Presses Universitaires France.

Doob, Leonard W. (1950) Goebbels' Principles of Propaganda. The Public Opinion Quarterly, Vol. 14, No. 3 (Autumn). 419-442. https://www.jstor.org/stable/2745999, https://doi.org/10.1086/266211

Eco, Umberto (1976) A rossz ízlés struktúrája. (Fordította Szabó Győző) In: Eco, Umberto (1976) A nyitott mü. Budapest, Gondolat.

Ellul, Jacques (1973) Propaganda: The Formation of Men's Attitudes. New York, Vintage Books.

Fekete Ferenc (1940) A reklám és a propaganda. Korunk, 1940/2. 111-116. http://www.epa.oszk.hu/00400/00458/00360/pdf/Korunk_EPA00458_1940_02_111-116.pdf

Herman, Edward - Chomsky, Noam (2016) Az egyetértés-gépezet: A tömegmédia politikai gazdaságtana. Budapest, L' Harmattan. (Ford. Herman, Edward - Chomsky, Noam: Manufactoring Consent: The Political Economy of the Mass Media. New York, Pantheon Books, 1988)

Hunt, Lynn (1984) Politics, Culture, and Class in the French Revolution. Berkeley - Los Angeles, University of California Press.

Jakusné Harmos Éva (2005) A kereskedelmi és a politikai propaganda nyelvi eszközei. Magyar Nyelvör, 129/4. 419-436.

Kiss Balázs (2006) Missziótól marketingig. Médiakutató, 2006/tavasz. http://www.mediakutato.hu/cikk/2006_01_tavasz/01_missziotol_marketingig 
Klapper, Joseph (1969) A tömegkommunikáció hatásai. Budapest, MRT Tömegkommunikációs Kutatóközpont. (Ford. Klapper Joseph: The Effects of Mass Communication. Glencoe, Illinois, The Free Press, 1960)

Lasswell, Harold D. (1927) Propaganda Technique in the World War. New York, Knopf. https://hdl.handle.net/2027/mdp.39015000379902

Le Bon, Gustave (1913) A tömegek lélektana. Budapest, Franklin Társulat.

Macskássy Gabi (1998) Légy résen, avagy egy veszélyes műfaj. In: Miháncsik Zsófia - Vándor Ágnes (szerk.) Reklámvonal '98. Irások, elemzések interjúk a magyar reklámkommunikáció világából. Budapest, Kreutz Studio Kommunikációs Szolgáltató Kft.

McLuhan, Herbert Marshall (1964) Understanding Media, The Extensions of Man. London, Routledge.

Múlt-Kor (2018) Hitler propagandagépezete. https://mult-kor.hu/hitler-propagandagepezete-20180925

Németh István (2016) A propagandáról a Mein Kampfban és megvalósulása a harmadik birodalomban. Rubicon 27. évf. 3. szám (2016. március) 69-75. https://docplayer.hu/108328750-68-rubicon-tortenelmi-magazin.html

Pratkanis, Anthony R. - Aronson, Elliot (1992) A rábeszélőgép - élni és visszaélni a meggyözés mindennapos mesterségével. Budapest, Ab Ovo.

Ries, Al - Trout, Jack (1996) Marketingháború. Budapest, Bagolyvár Könyvkiadó.

Rosengren, Karl Erik (2008) Kommunikáció. Budapest, Typotex.

Rudas János (2012) A törzsfönök esete a propagandával. Magyar Narancs. 2012/19. (05.10)

Schiller, Friedrich (1960) Levelek az ember esztétikai neveléséröl. In: Vajda György Mihály (1960szerk.) Schiller válogatott esztétikai irásai. Budapest, Magyar Helikon.

Urbányi János (1930) A reklám kézikönyve. A kereskedelmi szakoktatás könyvtára. Budapest, Kereskedelmi Szakiskolai Tanárok Országos Egyesülete.

Virányi Péter (2017) Több mint reklámtörténelem. Budapest, Gondolat. 